\title{
HUBUNGAN BEBAN KERJA DENGAN KINERJA KARYAWAN DI RUMAH SAKIT NUR HIDAYAH BANTUL
}

\author{
Ahmad Ahid Mudayana \\ Fakultas Kesehatan Masyarakat, Universitas Ahmad Dahlan, Yogyakarta
}

\begin{abstract}
Background: The process of development is Nur Hidayah Hospital (RS Nur Hidayah) Bantul makes employees work load increases. Improved performance the hospital can improve employee performance. If the employees performance is getting better, the service given to the patients will be getting better too. The researcher interested to do research the relationship of workload with performance of employees.

Method: This was descriptive research using cross sectional approach. Research of method that used quantitative, the number of 79 employees' respondents. The data analyzed using correlation analysis. Workload assessed by questionnaire, performance while using a checklist.

Result: Performance $(92,4 \%)$ employees are included in the high category, while for the majority of the workload of employees included in the medium category with a percentage 54,4 $\%$. There is no significant relationship of workload with employee performance $(p(0,066)>0,05)$. Conclusion: This study shows employee performance is already high. There is no significant relationship of workload with employee performance Nur Hidayah Hospital in Bantul.
\end{abstract}

Key words: Work load, performance

\section{PENDAHULUAN}

Penilaian kinerja merupakan proses kontrol kinerja karyawan yang dievaluasi berdasarkan standar tertentu. ${ }^{1}$ Penilaian kinerja dilakukan secara efektif untuk mengarahkan perilaku karyawan dalam rangka menghasilkan jasa dengan kualitas yang tinggi. Manfaat lain dari penilaian kinerja antara lain digunakan untuk perbaikan prestasi kerja, penyesuaian kompensasi, kebutuhan pengembangan, serta melihat penyimpangan maupun kesalahan dalam pekerjaan. ${ }^{2}$ Kegunaan tersebut mengharuskan penilaian kinerja mampu memberikan gambaran yang akurat dan obyektif mengenai prestasi kerja karyawan.

Mayoritas karyawan Rumah Sakit Nur Hidayah Bantul saat ini berstatus sebagai karyawan tetap dan sebagian karyawan tidak tetap. Karyawan tidak tetap saat ini menggunakan sistem kerja kontrak. Beberapa bagian rumah sakit masih kekurangan karyawan, sehingga beberapa karyawan diberi tanggung jawab ganda yang berdampak pada beban kerja yang akan meningkat. Untuk mengatasi pekerjaan ganda karyawan, sebelumnya dilakukan analisis pekerjaan terlebih dahulu agar beban kerja yang diterima tidak terlalu berlebihan dengan adanya penambahan beban kerja sehingga karyawan bisa bekerja dengan maksimal. Meskipun beberapa karyawan berstatus pegawai tidak tetap, akan tetapi itu bukan menjadi masalah serius bagi rumah sakit. Justru ini dijadikan sebagai salah satu strategi untuk meningkatkan kinerja rumah sakit dengan pegelolaan manajemen sumber daya manusia yang baik. Hal ini juga harus tetap diwaspadai oleh manajemen apabila tidak memiliki persediaan suplai karyawan. Adanya proses pengembangan rumah sakit menjadikan beban kerja karyawan meningkat karena karyawan dituntut untuk mengeluarkan seluruh potensi yang dimilliki. Beban kerja yang meningkat menjadikan penilaian kinerja yang dilakukan oleh manajemen 
menjadi sangat penting karena berkaitan dengan prestasi kerja serta besaran insentif yang akan diterima oleh karyawan.

Seluruh karyawan memiliki job description masing-masing yang sudah ditentukan oleh pihak manajemen rumah sakit, tetapi implementasinya belum dilaksanakan secara maksimal. Ini dibuktikan dengan masih adanya komplain ketidakpuasan dari masyarakat terkait pelayanan yang diberikan terutama di ruang rawat inap. Evaluasi yang dilakukan belum berlangsung secara rutin dan berkala juga menjadi kendala untuk mengukur tingkat implementasi job description, karena evaluasi selama ini hanya sebatas insidental sesuai kebutuhan manajemen. Sedangkan penilaian kinerja perawat saat ini hanya sebatas digunakan untuk pemberian gaji serta besaran insentif yang akan diterima sesuai dengan jumlah poin yang didapat.

Di samping itu, masih ada beberapa karyawan yang dibebani tugas ganda karena keterbatasan sumber daya yang dimiliki sehingga banyak karyawan yang masih merangkap jabatan dan tugas. Banyaknya tugas dan tanggung jawab yang diberikan kepada karyawan menyebabkan hasil yang dicapai menjadi kurang maksimal karena karyawan hanya mempunyai waktu yang sedikit untuk menyelesaikan banyak tugas.

Belum dilaksanakannya job description yang sudah dibuat secara maksimal oleh karyawan rumah sakit akan berdampak pada hasil penilaian kinerja sebagai bahan evaluasi bagi manajemen rumah sakit. Perlu dilakukan upaya untuk memotivasi karyawan agar mampu melaksanakan tugasnya dengan baik sesuai job description yang sudah ditetapkan. Apabila ini tidak dilakukan maka akan berdampak pada penurunan kualitas kerja serta menurunnya kualitas pelayanan kesehatan yang selama ini sudah cukup baik. Tanggung jawab yang diberikan kepada karyawan juga terlalu besar yang berakibat pada beban kerja yang meningkat dan dapat berpengaruh kepada kinerja karyawan sehingga menjadi tidak maksimal. Menelaah latar belakang di atas maka peneliti tertarik untuk melakukan penelitian mengenai hubungan beban kerja dengan kinerja karyawan di RS Nur Hidayah Kabupaten Bantul.

\section{METODE PENELITIAN}

Jenis penelitian ini adalah deskriptif dengan rancangan cross sectional. Penelitian ini bertempat di Rumah Sakit Nur Hidayah Kabupaten Bantul. Subjek penelitian ini berjumlah 79 karyawan RS Nur Hidayah. Instrumen yang digunakan kuesioner dan check list. Hasil uji reliabilitas untuk variabel beban kerja didapat nilai alpha 0.739 lebih besar dari nilai tabel sehingga instrumen tersebut reliabel. Hasil analisis reliabilitas untuk variabel kinerja didapat nilai alpha 0.757 sehingga instrumen dinyatakan reliabel. 
3. HASIL PENELITIAN DAN PEMBAHASAN

\section{A. Hasil Penelitian}

Tabel 1. Data Frekuensi Profesi Responden Karyawan RS Nur Hidayah Bantul

\begin{tabular}{lcc}
\hline \multicolumn{1}{c}{ Profesi } & Frekuensi (n) & Persentase \\
\hline Perawat/Asisten perawat & 27 & 34,2 \\
Dokter & 11 & 13,9 \\
Administrasi & 11 & 13,9 \\
Pemeliharaan/keamanan & 8 & 10,1 \\
Kerumah tanggaan & 7 & 8,9 \\
Apoteker/Asisten apoteker & 6 & 7,6 \\
Analis kesehatan & 4 & 5,1 \\
Radiografer & 3 & 3,8 \\
Bidan & 2 & 2,5 \\
\hline Jumlah total & $\mathbf{7 9}$ & $\mathbf{1 0 0}$ \\
\hline
\end{tabular}

Berdasarkan tabel diatas dapat dilihat bahwa mayoritas responden dalam penelitian ini yaitu perawat/asisten perawat. Kemudian diikuti dokter dan pegawai administrasi.

Tabel 2. Frekuensi Variabel Beban Kerja dan Kinerja Karyawan RS Nur Hidayah Bantul

\begin{tabular}{lcc}
\hline \multicolumn{1}{c}{ Variabel } & Jumlah $(\mathbf{n})$ & Persentase $(\%)$ \\
\hline $\begin{array}{ccc}\text { Beban Kerja } \\
\text { Tinggi }\end{array}$ & 36 & 45,6 \\
Sedang & 43 & 54,4 \\
Kinerja & & \\
Tinggi & 73 & 92,4 \\
Sedang & 6 & 7,6 \\
\hline
\end{tabular}

Sebagian besar motivasi kerja karyawan RS Nur Hidayah berada dalam kategori tinggi. Tidak ada karyawan yang masuk dalam kategori rendah. Pada tabel diatas juga diketahui bahwa 54,4\% karyawan memiliki beban kerja sedang dan sebanyak $45,6 \%$ karyawan memiliki beban kerja yang tinggi. Tidak ada karyawan yang memiliki beban kerja rendah. Sedangkan untuk kinerja menunjukkan bahwa sebagian besar karyawan mempunyai kinerja yang tinggi dengan persentase mencapai $92,4 \%$ dan hanya $7,6 \%$ karyawan yang mempunyai kinerja sedang. Tidak ada karyawan yang masuk dalam kategori kinerja rendah (lihat tabel 2). 
Tabel 3. Frekuensi sub variabel beban kerja karyawan RS Nur Hidayah Bantul

\begin{tabular}{lcccc}
\hline \multicolumn{1}{c}{ Variabel } & Mean & Minimum & Maksimum & Nilai total \\
\hline Beban Kerja & 58,3 & 49 & 71 & 76 \\
\hline Quantitative workload & 14.3 & 9 & 19 & 20 \\
Qualitative workload & 21.0 & 17 & 28 & 28 \\
Workload variabilty & 22,9 & 18 & 28 & 28 \\
\hline
\end{tabular}

Rata-rata beban kerja karyawan RS Nur Hidayah sudah cukup tinggi yaitu sebesar 58,3 dari total nilai 76 . Pada sub variabel beban kerja diketahui bahwa workload variability mempunyai rata-rata tertinggi sebesar 22,9 diikuti qualitative workload dengan rata-rata 21 dan terakhir quantitative workload dengan rata-rata 14,3 (lihat Tabel 3).

Tabel 4. Hubungan beban kerja dengan kinerja karyawan RS Nur Hidayah Bantul

\begin{tabular}{ccc}
\hline \multirow{2}{*}{ Variabel } & \multicolumn{2}{c}{ Kinerja Karyawan } \\
\cline { 2 - 3 } & $\mathbf{R}$ & Sig(p) \\
\hline Beban kerja & 0,208 & 0,066 \\
\hline
\end{tabular}

Pada Tabel 4 menunjukkan beban kerja tidak memiliki hubungan dengan kinerja karyawan karena signifikan (p) 0,066 lebih besar dari 0,05.

Tabel 5. Hubungan sub variabel beban kerja dengan kinerja karyawan RS Nur Hidayah Bantul

\begin{tabular}{ccc}
\hline \multirow{2}{*}{ Variabel } & \multicolumn{2}{c}{ Kinerja Karyawan } \\
\cline { 2 - 3 } & $\mathbf{R}$ & Sig(p) \\
\hline Beban Kerja & & \\
\hline Quantitative workload & $-0,030$ & 0,794 \\
Qualitative workload & 0,116 & 0,310 \\
Workload varibility & 0,239 & 0,034 \\
\hline
\end{tabular}

Sub variabel beban kerja didapat variabel workload variability memiliki hubungan yang rendah dengan kinerja karyawan. Sedangkan untuk sub variabel quantitative workload dan qualitative workload tidak memiliki hubungan signifikan dengan kinerja karyawan karena nilai signifikan ( $p$ ) lebih besar dari 0,05 (lihat Tabel 5). 


\section{B. Pembahasan}

Beban kerja sebagian besar karyawan pada umumnya sedang dengan persentase $54,4 \%$. Tetapi perbandingan dengan karyawan yang memiliki beban kerja sedang sangat tipis yaitu $45,6 \%$. Beban kerja karyawan perlu diperhatikan agar tidak terjadi over yang dapat menimbulkan stres dan berakibat pada menurunnya kinerja karyawan. Meskipun tidak berpengaruh secara langsung akan tetapi dapat menimbulkan stres yang berakibat pada performance karyawan. Beban kerja yang tinggi dapat menimbulkan stres sehingga mempengaruhi kinerja. ${ }^{3}$

Faktor beban kerja terdiri dari quantitative workload, qualitative workload dan workload variability. Dari ketiga faktor tersebut workload variability merupakan faktor yang paling tinggi dalam beban kerja karyawan. Workload variability terjadi karena naik turunnya beban kerja yang diterima oleh karyawan seperti tinggi rendahnya beban shift kerja yang diterima dalam bekerja melayani pasien dengan intensitas pasien yang banyak. ${ }^{4}$ Beban shift yang diterima dapat mempengaruhi karyawan dalam memberikan pelayanan kesehatan yang bermutu. Beban kerja dapat mempengaruhi stres kerja karyawan selain itu juga dapat mempengaruhi pelayanan kepada pasien serta keselamatan pasien sehingga kinerja perawat menjadi rendah. ${ }^{5}$ Tingginya beban kerja dapat mengakibatkan terjadinya stres kerja pada dokter yang dapat mempengaruhi menurunnya kinerja dokter di Belanda. ${ }^{6}$ Hal ini menunjukkan bahwa semakin tinggi beban kerja yang diterima dapat menyebabkan stres kerja sehingga bisa mempengaruhi kinerja.

Berdasarkan hasil penelitian ini didapat bahwa tidak ada hubungan beban kerja dengan kinerja karyawan $(p(.066)>, 05$. Beban kerja tidak berpengaruh secara langsung terhadap kinerja karyawan. Akan tetapi, beban kerja berpengaruh terhadap stres yang dapat mempengaruhi kinerja para karyawan. ${ }^{3}$ Bisa dikatakan bahwa besar kecilnya beban kerja tidak akan mempengaruhi kinerja karyawan selama mereka tidak mengalami stress.

Secara umum beban kerja tidak berhubungan dengan kinerja karyawan akan tetapi, apabila dilihat dari sub variabel ada sub variabel yang memiliki hubungan dengan kinerja karyawan. Workload variability memiliki hubungan dengan kinerja karyawan. Workload variability memiliki pengaruh terbesar diantara faktor-faktor beban kerja lainnya dan berpengaruh terhadap kinerja perawat di ICU (Intensive Care Unit) yang dikarenakan tingginya beban kerja yang harus diterima. Semakin bervariasi shift yang diterima perawat termasuk dalam kategori workload variability sehingga menyebabkan stres pada perawat di ruang ICU's (Intensive Care Unit's) dan dapat dikatakan beban kerja mempunyai hubungan dengan stres kerja yang dapat mempengaruhi kinerja. ${ }^{5}$

Beban kerja tidak berhubungan secara langsung dengan kinerja, tetapi pihak manajemen juga perlu memperhatikan secara serius beban kerja yang diterima oleh karyawan. Apabila beban kerja yang diterima terlalu besar maka akan dapat menimbulkan stres kerja yang bisa mempengaruhi motivasi kerja dan menurunnya kinerja. ${ }^{6}$ Perlu dilakukan evaluasi secara terus menerus serta memonitoring beban kerja para karyawan agar tetap berada dalam batas yang wajar dan sesuai dengan tugas yang telah diberikan. Beban kerja yang normal dapat mempertahankan kinerja karyawan karena karyawan akan merasa nyaman dan tidak mengalami stres dalam bekerja sehingga kinerja mereka menjadi lebih baik.

Berdasarkan hasil penelitian ini juga bisa dikatakan bahwa besar kecilnya beban kerja yang diterima karyawan RS Nur Hidayah Bantul tidak mempengaruhi kinerja karyawan. Karyawan akan tetap bekerja dengan baik 
meskipun beban kerja yang diterima tinggi atau sedang selama mereka masih termotivasi dalam bekerja. Akan tetapi, beban kerja yang diterima karyawan juga tetap perlu diperhatikan meskipun tidak berpengaruh terhadap kinerja mereka agar tidak terjadi beban kerja yang terlalu tinggi yang dapat menimbulkan stres yang berdampak pada kinerja karyawan.

\section{SIMPULAN DAN SARAN}

Tidak ada hubungan beban kerja dengan kinerja karyawan di RS Nur Hidayah Bantul. Ada hubungan sub variabel workload variability pada beban kerja dengan kinerja karyawan di RS Nur Hidayah Bantul. Tidak ada hubungan sub variabel beban kerja (quantitative dan qualitative workload) dengan kinerja karyawan di RS Nur Hidayah Bantul. Berdasarkan hasil penelitian ini maka kami menyarankan kepada pihak manajemen rumah sakit untuk melakukan evaluasi dan perbaikan terhadap beban kerja karyawan yang masih dalam kategori tinggi.

\section{DAFTAR PUSTAKA}

1. Samba, S., Pengantar Kepemimpinan \& Manajemen Keperawatan Untuk Perawat Klinis, EGC, Jakarta. 2000

2. Handoko, T.H., Manajemen Personalia \& Sumber Daya Manusia, BPFE, Yogyakarta. 2008

3. Glaser, N.D. Tatum, BC. Nebeker, MD. Sorensen, CR. Aiello, RJ., Workload and Social Support : Effects on Performance and Stress, Human Performance, 12(2), 155-176. 1999

4. Carayon, $P$ dan Alvarado, JC., Workload and Patient Safety Among Critical Care Nurses. Critical Care Nursing Clinics on North America 19, 121-129. 2007

5. Gurses, P Ayse. Carayon, P. Wall, Melanie, Impact of Performance Obstacles on Intensive Care Nurses Workload, Perceived Quality and Safety of Care, and Quality of Working Life, Health Research and Educational Trust 934, 422-443. 2008

6. Hombergh, Pieter van den. Kunzi, Beat. Elwyn, Glyn. Doremalen, Jan van. Akkermans, Reinier. Grol, Richard. Wensing, Michel, High Workload and Job Stress are Associated with Lower Practice Performance in General Practice : An Observational Study in 239 General Practices in Netherlands. BMC Health Service Researh 9:118, 1-8. 2009 